\title{
Research on the construction of music appreciation ecological classroom and the innovation of teaching methods
}

\author{
$\mathrm{Li} \mathrm{Yu}^{1}$ \\ ${ }^{1}$ School of Music, Sichuan Normal University, Chengdu, Sichuan, 610000, China
}

\begin{abstract}
Music appreciation is one of the indispensable courses. It plays a key role in cultivating students' aesthetic ability and perfecting students' personality. The purpose of the Ecology Curriculum is to create an equal and relaxed classroom atmosphere between the teachers and students during the course of the course. Let students and teachers grow together in this harmonious and happy environment, aiming at the problems that the existing courses are not valued, the teaching content is not cautious, and the teaching materials are not standardized. This paper proposes that on the one hand, it is necessary to improve the music appreciation ecological course, on the other hand, it is necessary to improve the teaching method. Measures to improve the Ecology Course for Music Appreciation include a complete teaching, a clear teaching plan and appropriate textbooks. The diversification of teaching methods and the enrichment of educational models are also important methods for innovative teaching methods. At the same time, it is important that students have the right learning concept in the music appreciation course and the school's support for the faculty and equipment.
\end{abstract}

\section{Introduction}

In this era, music has become an indispensable part of the life of most students. As a public elective course for, the Music Appreciation Course has been widely welcomed by students. Therefore, it is one of the main tasks faced by every college by offering high-quality music appreciation ecological courses and cultivating students with all-round development.

As a course to cultivate sentiment, the Music Appreciation Course plays a vital role in the growth of students. In the process of learning, exploring and enjoying music, students will use the power of music to clean up dirt, cultivate sentiment, purify the soul, and open up a better future. The importance of setting up a music appreciation course is divided into three areas:

(1) Helps to improve students' moral quality. Music education runs through all stages of student development, from elementary school to junior high school and high school, and also forms part of university education. At the same time, the education of music is different from other courses, not just simple memorization and memory can be completed. It is a resonance between the teacher who teaches music and the student who learns on the basis of music. That is, teachers and students communicate through music. The emotional power transmitted in the music tracks constantly infects every listener. Therefore, the positive energy transmitted in music can also affect the formation of students' excellent moral quality.

(2) Helps develop a healthy personality. The ultimate goal of education is to cultivate people who are healthy, healthy, and healthy. Music in its invisible form imperceptibly affects the formation of students' personality. Music is immersed in every detail of the student's learning and life. A healthy personality should be formed in a beautiful environment, and music is a key component of this environment. At the same time, different students have different aesthetics about music. This is largely due to the difference in student personality and the experience of life, so the emotions that are understood are different. How to cultivate students' sound personality is one of the purposes of setting up music appreciation classes in colleges and universities.

(3) Helps improve students' aesthetic ability. For a fully developed person, having a certain aesthetic ability is essential. Music appreciation teaching is one of the important ways to cultivate students' aesthetic ability. Having a certain musical appreciation ability is also part of the aesthetic ability. The specific measure for cultivating students with certain aesthetic ability is to offer high-quality music appreciation ecological courses. Through the music appreciation course, students can not only intuitively feel the charm of music works, but also understand the structure, theme and emotion of the music under the guidance of teachers. Therefore, the Music Appreciation Course is one of the effective ways for to improve students' aesthetic ability.

In view of the shortcomings of the teaching model in the traditional classroom, the advantages of the ecological classroom are increasingly exposed. Different from the one-to-many passive teaching mode in the traditional teaching mode, the emphasis in the ecological curriculum is the equal relationship between teachers and students. Classroom activities are more flexible. The classroom atmosphere is more relaxed and natural. In this equality relationship, it is separated from the limitations of the 
dominant and the dominant. In different questions, students can speak freely and become the leader of this module. Such a classroom meets the laws of natural development of people. The successful introduction of the ecological classroom is not only beneficial to the healthy development of the students, but also beneficial to the teachers for the growth of the teachers. In this process, the classroom can fully obtain the feedback information in the teaching activities through interaction with the students, so as to make adjustments and constantly improve themselves.

\section{Problems in the Music Appreciation Course}

(1) Teaching content is more difficult to choose. According to statistics, $80 \%$ of the students in the music appreciation courses of are from Social science and art of music majors. Because the students of the Music Appreciation Class have different professions, the level of appreciation for music is also very different. For the situation where the basic level is uneven, it is difficult to determine the difficulty of the teaching content in the music appreciation ecological course. The teaching content is too simple, and the course is bound to produce a boring feeling, which is a blow to students' enthusiasm for learning. The difficulty of teaching content can't be understood by students, and it is bound to make students feel tired of learning. Figure 1 shows the composition of the students majoring in the Music Appreciation Ecology Course. It can be seen that most of the students in the class are Social science and art of music majors. Most Social science and art of music students have limited ability to appreciate music. Therefore, the difficulty of teaching content is difficult to grasp. This is the first problem that needs to be solved urgently.

(2) Students have no clear understanding of music appreciation course. Students only focus on courses related to their majors because of the nature of the school. Courses such as music appreciation are chosen for the purpose of taking credits. First of all, the mentality that students hold is wrong. Too utilitarian, focusing only on practical courses related to the profession, while ignoring the potential role of the course. Moreover, because the music foundations of non-music students are generally biased, most students do not have much confidence in learning this course. How to improve students' confidence in this course is also a very important issue. Finally, for this type of course, most colleges do not have rigid test requirements, which to some extent makes students relax their learning and stop learning. This is the second problem that needs to be solved urgently.

(3) Improper selection of textbooks. Most music appreciation courses do not have textbooks. The teacher does not have a systematic reference to the teaching objectives, and the specific teaching content can only be determined by himself. Although the teacher is given greater initiative and space, it is inevitable that there will be incomplete considerations during the course setting process. In addition, the teacher's musical knowledge may be domain-based, so setting the course content may focus on the areas in which he is good at it. However, this does not guarantee the systematic nature of the course content. On the other hand, students can only learn the content of this lesson by watching the teacher's PPT. Therefore, students cannot form a systematic curriculum system, but are familiar with the content of this lesson, but do not understand the connection between the previous and the following courses. Students are also unable to complete after-school review and preparation before class. Therefore, the teaching effect will be greatly reduced. This is the third problem that urgently needs to be resolved. Moreover, since there is no uniform teaching material, the teaching content is completely determined by the teacher's ideas. Therefore, it is more difficult to exchange music appreciation courses between different colleges.

(4) Insufficient schedule and insufficient number of teachers. Not only most students do not pay much attention to the music appreciation courses, but also do not attract enough attention from the school. As a nonprofessional course, it is a whole-school curriculum that enhances students' comprehensive music appreciation. The school usually ignores the importance of this course. We want to cultivate talents with comprehensive qualities of moral, intellectual, and aesthetic development. Music appreciation classes, as a must-have course, play a vital role in the students' learning process. However, because of the lack of attention to such mistakes, the course time of the course is directly shortened due to changes in many factors. Even for a quality course, once the course time is not guaranteed, the quality of the course will be directly limited.

Assuming that $I=\left\{i_{1}, i_{2}, \ldots, i_{n}\right\}$ is a set of all items, $T=\left\{t_{1}, t_{2}, \ldots, t_{n}\right\}$ is a set of all things, and the set of items

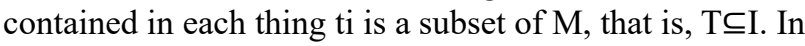
association analysis, a set containing 0 or more items is called an item set. The number of things that contain a specific item set is called the support count of item set, and the support count of item set can be recorded as $\sigma(A)$. Association rules are implicit expressions in the form of $\mathrm{A} \rightarrow \mathrm{B}$, where $\mathrm{A} \subset \mathrm{I}, \mathrm{B} \subset \mathrm{I}$, and $\mathrm{A} \cap \mathrm{B}=\Phi$. The strength of the rules can be measured by Support (S)and Confidence(C), which are defined as follows:

$$
\begin{aligned}
& S(A \rightarrow B)=\frac{\sigma(A \cup B)}{N} \\
& C(A \rightarrow B)=\frac{\sigma(A \cup B)}{\sigma(A)}
\end{aligned}
$$

where $\mathrm{N}$ is the total number of things.

Due to the lack of awareness of students and the school, the teaching resources for music appreciation are also very scarce. The limited number of teachers assigned to this course means that the workload of teachers will increase significantly. A teacher needs to teach more students and be responsible for more classes. The increase in workload will inevitably increase the teaching pressure of teachers. Therefore, the quality of the music appreciation ecological course cannot be effectively guaranteed. 


\section{The improvement measures of music appreciation ecological classroom}

The improvement measures for the whole music appreciation ecological classroom mainly include two aspects: the construction of music appreciation ecological classroom and the innovation of teaching methods.

Music appreciation of the construction of ecological classroom: (1) Choose suitable teaching materials and diversify teaching contents. The teaching material is one of the most important teaching tools in the teaching process, so the selection of the teaching material is directly related to the success of the music appreciation ecological course. The beauty of music in the world is diverse, which enables students to feel the charm of music as much as possible in the course. It is the core of the course of music appreciation of ecology. So, the teacher must choose the teaching material from many angles to carry on the reasonable consideration. The purpose of the music should be diversified, the representativeness of the music should be guaranteed, and the number of the music should be determined from the time of the semester.

In music teaching, multi part chorus teaching has always been a very important content in music teaching, which has positively impacted on students' music aesthetic feeling and music skills. It is also a difficult point for teaching. considerding the practical experience of multi parts teaching in music chorus teaching, first of all, teachers should guide students to train the music rhythm by the principle of shallow and deep; secondly, teachers should focus on training students' ability to distinguish multi parts. Finally, strengthen the harmony training. As the most advanced organization in the multi part music, harmony is one of the effective performance ways of music singing. In the teaching of music harmony, listening practice should be carried out at the same time with the training of harmony part.

The choice of teaching content should both guarantee its quality and control the difficulty of the course. The content of the teaching should be determined to make the content of the course rich. Table1 shows the three dimensions of the course selection, which can be based on the selection of course content based on these three dimensions.

Table1. Selection of course content

\begin{tabular}{ccc}
\hline Angel & classification & Songs \\
\hline Angles1 & $\begin{array}{c}\text { The ancient and } \\
\text { modern } \\
\text { Chinese and } \\
\text { foreign }\end{array}$ & $\begin{array}{c}\text { The Butterfly Lovers and } \\
\text { Etude in C sharp minor } \\
\text { Departure at the fron and } \\
\text { Czech fields and forests }\end{array}$ \\
Angles2 & $\begin{array}{c}\text { The refined and } \\
\text { vulgar }\end{array}$ & $\begin{array}{c}\text { Etude in C sharp minor And } \\
\text { A tune in Yimeng mountain }\end{array}$
\end{tabular}

Table 1 is the three perspectives for the selection of teaching content, which are the angles of the past and the present, the angles of the middle and the outer, and the angles of elegance and vulgarity. The third column is an example of selecting tracks for each different angle.

(2) Multi - design course plan, diversified teaching forms. The traditional mode of education is that the teacher speaks alone, and many students listen to the audience. This mode of teacher-student interaction is poor, which is not conducive to the improvement of students' perception and the understanding of teaching content is not high. In the music appreciation ecological classroom, we can set up a variety of teaching programs, so that each student can participate in the classroom in a variety of ways. For example, the story contest related to the background of the track can be used to let the students deeply understand the author's creative environment, which is of great benefit to the appreciation of the whole track. Interest is the best teacher. To improve students' interest, it is necessary to change the teaching methods and diversify the teaching methods. The advanced teaching methods used have improved students' interest in learning, analysis and problem solving. For example, through the combination of sound and image of composition, it can greatly enhance students' interest. In addition, it is also necessary to focus on the combination of heuristic, interactive, dynamic and static teaching methods.

(3) Arrange teaching schedule reasonably. The teaching plan for the music appreciation ecological course must be practical and adaptable to the students' ability to accept. In the early stage, it is necessary to start with the appreciation of some simple tracks to avoid the difficulty of the songs and the enthusiasm of students. Then, it is necessary to gradually increase the difficulty of the track, and the appreciation of the appropriate amount of difficulty will promote the improvement of the student's appreciation ability. In addition, if the long-term is a less difficult track, it will certainly appear that the course is boring and will also hamper students' enthusiasm for learning the music appreciation course.

(4) Pay attention to the implementation of ecological curriculum. The biggest difference between the ecological curriculum model and the traditional educational model is that in the ecological classroom, the degree of equality and liberalization between teachers and students is higher. Unlike the one-to-many model in traditional education, the ecological curriculum also pays attention to the many-to-many relationship. The exchange and cooperation between students and students are also one of the important ways to promote students' understanding of music appreciation courses. The ultimate goal of the Music Appreciation Ecology Program is to give the majority of students a sense of musical fascination.

(5) Increase equipment investment to meet teaching needs. The music appreciation course is mainly used as a comprehensive course of the whole school. Therefore, should make reasonable classroom arrangements according to the number of students selected, not only to ensure the integrity of teaching, but also to ensure the quality of teaching. For example, simply choosing an empty large classroom to increase the number of students in the class, while ignoring the echo and emptiness of the classroom, will directly reduce the quality of the appreciation course.

In addition to the appropriate classrooms and basic multimedia playback equipment, the quality of audio equipment should also be effectively guaranteed. Only by guaranteeing the quality of the hardware can we really give full play to the special role of this course.

Innovation in teaching methods: (1) Establish a 
complete teaching system. It is precisely because of the prior emphasis on music appreciation classes that this course does not form a complete teaching system framework. Having a complete teaching system framework is essential for a course. The complete teaching system includes clear teaching objectives and teaching directions, standardized teaching plans, feedback on student learning in the later stages, and reflection after teaching. Table 2 shows a complete teaching process:

Table2. Teaching Process of Music Appreciation Course

\begin{tabular}{|c|c|}
\hline Teaching process & Specific forms \\
\hline Import section & $\begin{array}{l}\text { Poetry reading; storytelling; film } \\
\text { display }\end{array}$ \\
\hline $\begin{array}{c}\text { Teaching } \\
\text { implementation }\end{array}$ & Play and enjoy \\
\hline $\begin{array}{c}\text { Experience and } \\
\text { understand }\end{array}$ & scene performance; video material \\
\hline Teaching feedback & $\begin{array}{c}\text { Experience; emotional } \\
\text { communication }\end{array}$ \\
\hline Classroom summary & $\begin{array}{c}\text { Teaching reflection; Summary and } \\
\text { improvement }\end{array}$ \\
\hline
\end{tabular}

Table 2 shows a complete set of teaching processes, including the introduction of the situational interactions of teachers and students in the early stage, and the selfreflection of the teachers in the later stages. Only having this complete teaching plan is the key to a quality and enjoyable music appreciation ecological course.

(2) Define teaching objectives and change teaching methods. The purpose of the implementation of the music appreciation ecological classroom is to strengthen the quality education with aesthetics as the core. In order to achieve the success of the music appreciation course teaching, it is necessary to update the teaching concept. If the educational thought is divorced from the actual situation, it will inevitably affect the development of music education throughout the school. On the one hand, the teaching objectives cannot be set too high, and most non-professional students cannot be required to appreciate the music professional. On the other hand, it is necessary to ensure the original setting purpose of the music appreciation ecological classroom, and it is necessary to improve the students' ability to appreciate music to a certain extent. Otherwise, if the teaching goal is set too low, the teaching effect will not be good.

(3) The construction of targeted teaching model. In addition, in the process of music education, effective and feasible teaching objectives are also formulated according to the characteristics of students. In the real practical teaching process, there will be various problems. Under this circumstance, teachers of can modify and increase the planned teaching plan according to the actual situation of most students in the school to adapt to the teaching environment and teaching requirements.

The ultimate goal of music appreciation is to improve the overall quality of college students. In teaching, teachers should teach according to different professional teaching characteristics, which not only reflects the professional characteristics of education, but also guarantees the teaching function of music. Teaching students in accordance with their aptitude is indispensable in the music appreciation ecological classroom. Each professional student has a different field of expertise. In addition, it requires a certain amount of perception and understanding for music appreciation. In this respect, the Social science and art of music department Some students may be lacking, so it is crucial to propose different teaching plans and different teaching instructions for different situations.

(4) Increase investment in teachers and improve students' basic ability. In order to better improve the quality of students' music appreciation classes and improve students' musical appreciation, it is also essential to invest in masters. The faculty is strong, the quality of the teacher's preparation is guaranteed, and the quality of the music appreciation ecological class is greatly improved, and the goal of improving the students' music foundation ability can be realized naturally.

\section{Conclusion}

The Music Appreciation Ecology Curriculum is an indispensable course. It is necessary to improve the efforts and cooperation of teachers, students and schools in improving the music appreciation ability of most students. Only by properly setting teaching objectives, changing teaching concepts, diversifying teaching programs, and making ecological teaching course, teachers can truly improve this course. In order to complete the ultimate goal of our music appreciation eco-curriculum course: to enable students to obtain good music appreciation ability and become a comprehensive and qualified comprehensive quality talent that the society needs.

\section{References}

1. Weijia Zhang. Analysis on the Teaching Reform of Music Appreciation Course [J]. Journal of Chongqing Radio and Television University, 2010.2:19-21.

2. Xiaojun Liu, The Significance of Offering Music Appreciation Courses [J]. Great stage, 2010, (4): 145146.

3. Ming Cheng. Talking about the Importance of Music Appreciation Education [J]. Journal of Shanxi Youth Management Cadre College, 2007, 28(2):192-207.

4. Shaohong Huang. The Present Situation and Innovation of Music Appreciation Teaching [J]. New Technology of Library \& Information Service, 2009,03,31.

5. Hua Liu, The Promotion of Talent Appreciation Course [J]. Education, 2010, 51(3):187-200.

6. Jing Zeng. Research on the Teaching of Public Basic Courses in Music Appreciation [J] Enterprise Technology and Development. 2009:336-337.

7. Fu Z, Gatica L F , Sayas F J . Algorithm 949: MATLAB tools for HDG in three dimensions[J]. Acm Transactions on Mathematical Software, 2015, 41(3):1-21.

8. Jingyi Zhang. Teaching Status and Countermeasures of Music Appreciation Course in Art [J]. Hebei 
Education, 2017, J605-4;G712 .

9. Ting Wang. On the Cultivation of Music Appreciation Ability of Non-art Students.[J]. Vitality 2016 No. 5:30-31.

10. Jiaying Qin. Thoughts on Offering Music Appreciation Course for Non-music Majors [J]. Journal of Guangxi Administration of Politics and Law, 2011, No. 5:114-117.

11. Fu Z, Heuer N, Sayas F J. Coupling of HDG with a double-layer potential BEM[J]. Mathematics, 2012.

12. Jing Huang. Research on the Teaching of Music Appreciation Course in Colleges [J]. Practice innovation,. 2013, (4):269-270. 